\title{
Cotidianos além-mar: Júlio Horácio Bembe e Joaquim Paka Massanga
}

\author{
Everyday life beyond the sea: Júlio Horácio Bembe \\ and Joaquim Paka Massanga
}

\author{
Júnia Sales Pereira* \\ Júlio César Virgínio da Costa ${ }^{* *}$ \\ Luciano Magela Roza ${ }^{\star * *}$
}

Transcrição: Kelly Amaral Freitas (UEMG)

\section{Resumo}

A entrevista com os professores angolanos foi realizada durante o período de formação de Júlio Horácio Bembe e Joaquim Paka Massanga no Programa de Pós-Graduação em Educação da Faculdade de Educação da UFMG, em convênio com a Universidade Onze de Novembro (UON), Cabinda, Angola. Os dois docentes integram o grupo de trinta estudantes de mestrado e doutorado que entre 2012 e 2016 realizam os seus estudos de pós-graduação junto ao Programa, por meio de convênio entre a UFMG e a UON que se desdobra em múltiplas ações tanto no Brasil quanto em Angola, com intercâmbio bilateral. Bembe e Massanga foram selecionados por sua experiência profissional em Ensino de História em Angola. Ambos desenvolveram pesquisas de Mestrado pela UFMG entre 2012 e

\section{Abstract}

The interview with the Angolan teachers was held during the training period of Júlio Horácio Bembe and Joaquim Paka Massanga in the Graduate Program in Education of the Faculty of Education in the UFMG, Brazil, in partnership with the Onze de Novembro University (UON) in Cabinda, Angola. The two teachers take part on a group of 30 students of master's and doctoral, conducting their graduate studies at the program from 2012 to 2016, through an agreement between UFMG and the UON with multiple actions in Brazil and in Angola by bilateral trade. Bembe and Massanga were selected for their experience in History teaching in Angola. Both developed Master Degree research in the UFMG from 2012 to 2014 . Their interview revealed about teacher action,

\footnotetext{
* Doutora em História, Universidade Federal de Minas Gerais (UFMG); Ministério da Educação. juniasales@gmail.com

** Docente da Educação Básica em Minas Gerais e doutorando em Educação pela UFMG. juliocesarhistoria@gmail.com

*** Doutor em Educação pela UFMG e professor adjunto da Universidade Federal do Vale do Jequitinhonha e Mucuri (UFVJM).lucianoroza@gmail.com
} 
2014. A entrevista revela a realidade angolana em que se dá a atuação docente em História, os desafios da formação docente naquele país e as perspectivas de atuação com ensino de história sob a ótica de docentes. A entrevista realizou-se em 2013, por ocasião do Seminário Práticas Culturais Brasil-Angola, do Laboratório de Estudos e Pesquisas em Ensino de História da UFMG. about the challenges of teacher education and about the prospects of action with teaching history from the perspective of teachers in Angola reality. The interview took place in 2013, during the Cultural Practices Seminar Brazil-Angola, promoted by Laboratory of Studies and Research in the Teaching of History UFMG.

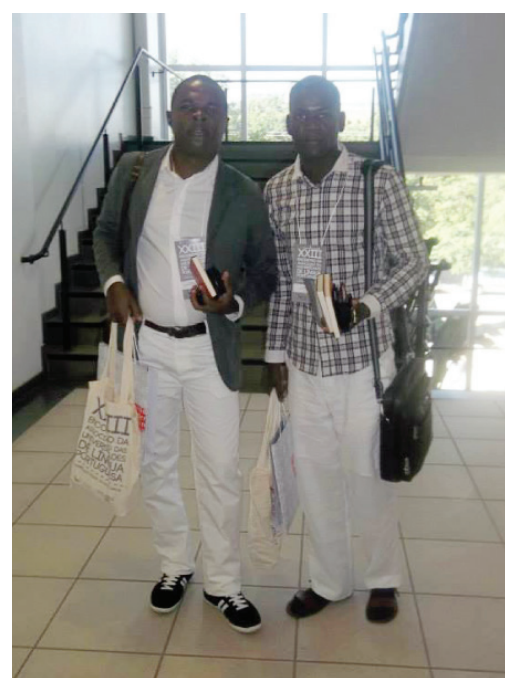

Júlio Horácio Bembe e Joaquim Paka Massanga em Seminário na Universidade Federal de Minas Gerais (UFMG), Belo Horizonte, 2013

A entrevista está organizada em dois blocos de questões, algumas delas mais voltadas à formação docente, outras relacionadas ao ensino de História e ao patrimônio e à diversidade em Angola, mais precisamente em Cabinda. Nesta primeira parte, uma questão que selecionamos é como têm sido as diretrizes, os pressupostos da educação em Angola, e também do ensino de História, pensando quais os fundamentos dessa educação. O ensino de História está voltado para quais finalidades? Considerando a educação como uma área 
extremamente estratégica, pensando a construção e o desenvolvimento de um país e, sobretudo, pensando em um país como Angola, de independência relativamente recente, como vêm se construindo esses pressupostos da educação em Angola e do ensino de História?

Júlio Horácio: Falar do ensino de história e da educação em Angola de forma geral, remete-nos a fazer um percurso daquilo que é a história do próprio país. Durante muito tempo, sobretudo no período colonial, a história de Angola não era ensinada, o país estava sob colonização portuguesa e o que se ensinava eram conteúdos da história de Portugal. Portanto os grandes homens que manipulavam a política e a economia portuguesa, os grandes problemas que o império português vivenciava na altura, enfim... A vida portuguesa é que se ensinava em Angola. Adquirida a independência, essa realidade não foi tão mutável, ou seja, não se mudou tanto essa prática, porque o país era novo, existiam poucos quadros formados na área de educação, daí que durante muitos anos, de 1975 até mais ou menos os anos 80 e princípio dos anos 90, o ensino de história estava muito vinculado à história de Portugal. Ora, depois surgiu o conflito armado que o país experimentou durante quase 3 décadas, que fragilizou a educação e o ensino de forma geral, porque os conteúdos ministrados eram conteúdos que de certo modo não se enquadravam com a realidade. Como hoje nós falamos da diversidade cultural, convém dizer que Angola é um país, do ponto vista cultural, com uma diversidade muito grande, e com isso eu penso que hoje deveria se ter em atenção esse aspecto. Hoje temos um ensino de história voltado a uma história conjunta, a uma história que não incide muito na questão particular. $\mathrm{O}$ que eu quero dizer com isso, por exemplo, hoje, aqui no Brasil, penso que cada estado procura elaborar a sua história, e essa história é aplicada a um determinado nível de ensino, mas em Angola isso não acontece. O que é ensino em Cabinda, ensina-se no Cunene e noutra parte do território nacional, mas com realidades extremamente diferentes, e penso que era por aí que tínhamos de partir, poderíamos até criar uma coisa mais global, mais conjunta, mas para um determinado nível de ensino tínhamos de particularizar. A região de Cabinda poderia estudar aspectos históricos daquela mesma região, a região do Zaire, de Luanda e assim sucessivamente, e num terminado nível fazer uma generalização. Portanto o processo de ensino está a passar de uma forma que começou nos primórdios dos anos 2000, e com isso os próprios conteúdos programáticos têm vindo a mudar, têm 
vindo a sofrer alterações, hoje vê-se nalguns conteúdos que o que se ensina hoje não é a mesma coisa que se ensinava há 2 ou 3 anos, por exemplo, e penso que há uma certa preocupação do Ministério da Educação e dos elementos que fazem os currículos, abordarem mais profundamente a questão da história de Angola com aquilo que acontece nas comunidades. Os políticos hoje procuram introduzir primeiro a questão da história de Angola para depois tentar compreender a história da África e depois fazer um link com a história universal, estamos a tentar partir para aquilo da nossa realidade, depois fazer um enquadramento do ponto de vista do continente Africano, e do continente Africano ver a coisa de forma mais ampla, de forma mais genérica. Penso que há muito trabalho ainda por se fazer neste sentido, porque a história de Angola não se circunscreve só, por exemplo, em lutas de libertação nacional. Quando falo de lutas de libertação nacional, remeto-me também às primeiras revoltas de grandes homens como o rei Mandume, Ekuikui I, aqueles grandes defensores de Angola, aqueles que não queriam que determinadas potências europeias conquistassem as suas terras, se organizavam mesmo com dificuldades, se organizavam para poderem proteger as suas zonas de origem, e essas lutas foram levadas a cabo por vários outros nacionalistas que vão depois trazer a independência de Angola. Então penso que a história de Angola está ainda em construção, e engrandecer a tarefa de todos nós angolanos em irmos trazendo alguma coisa naquilo que for necessário para enriquecer ainda mais os conteúdos da história de Angola.

Paka Massanga: Quero agradecer o convite para esse diálogo que está sendo muito bom. Acima de tudo nós estamos numa posição não de trazer, mas de receber nessa troca esse diálogo, nesse intercâmbio, nesse diálogo, cada vez mais está sendo enriquecedor para nós, enquanto professores.

Falar do processo de ensino e aprendizagem, a educação de Angola está muito ligada àquela transformação do país, de Angola já independente. Quando Angola obteve a independência, rompeu totalmente com toda forma de presença portuguesa, há uma cultura por detrás da colonização, então se recebe um país com carências dos quadros, com carências de suas estruturas, de escolas acima de tudo. Então o Partido no poder vai criar esforços e mecanismos para colmatar essa situação. Então é aí que se vê que durante muito tempo, as pessoas com $4^{\text {a }}$ classe em Angola foram chamadas para dar aulas não muito 
por questões de caráter pedagógico, mas porque havia necessidade de se formar e em busca do passado nas mãos dessas pessoas.

Então em Angola o MPLA de imediato assume o poder. Em 1977 foi criado o Partido do Trabalho, com a ideologia comunista, e a gente sabe que o marxismo, o socialismo e leninismo reinou fortemente, e os conteúdos didáticos eram todos versados nessa ideologia: o bem comum, a divisão equitativa, o proletariado. Então as pessoas foram educadas no poder do ensino patriótico, tudo sob orientação do partido do poder. E também dizer que nesse momento foram selecionados aqueles personagens que melhor convinham à ideologia e aos estados. Vamos caminhando...

Eu considero ser isto a primeira reforma do processo de ensino, porque de 1975 até 80,90 , até 89 , o ensino e os manuais também, apesar de haver uma mudança radical, não teriam um preparo técnico, então nos baseávamos mais nos manuais portugueses, e paulatinamente foi sendo substituído com essa ideologia partidária marxista-leninista.

Em 92, quando houve a paz com as organizações, aí veio o partidarismo, então havia uma necessidade maior de produção no processo de ensino. Então há mudanças nos próprios manuais, há mudanças nos conteúdos, há uma mudança grande, temos um país que vai crescendo, contávamos até aquele momento, 1992, com apenas uma única universidade, que é a Universidade Agostinho Neto, na qual tivemos o prazer de nos formar.

E fomos andando, retomamos a guerra em 1992, fomos até 2002, mais 10 anos de guerra. Mas antes de tudo o que resultou ou aconteceu em 2002? Em Angola foi aprovada ou foi criada a lei de base do sistema educativo Angolano, que é de 31 dezembro de 2001, então é nesse sistema que Angola se propõe a criar uma reforma no sistema educativo que já começa a utilizar elementos de 97/98, a introduzir novos elementos para processos de ensino, então vem a chamada fase da "reforma educativa". A prospectiva da reforma educativa foi grande para todos nós. E em 2001 aprova-se a lei se estabelece no sistema educativo para 2001, então essa lei vai estabelecer a reforma educativa com a generalização de 2007, e essa fase da reforma que estamos a acompanhar é que vai até 2015. Repare que antes de 2001, quando nós falávamos da questão do ensino da história, da questão da regionalidade, o que Júlio disse muito bem, o ensino 
era geral, quando estudamos na primária, vemos não haver nada sobre Cabinda, e só na $3^{\text {a }}$ classe a lição da nossa localidade é contada, questões como “em que províncias moras?”. E um dia se aplicou um trabalho - que chamam "para casa" do lado de cá, eu falava "tarefa para casa" -, "em que províncias moras?”. Ou assim, "como se chama seu país?" "Quantas províncias tem?" "Quantos municípios tem?” E assim a gente começa a saber um bocado sobre aquilo que é Angola, em particular Cabinda. Mas falar da questão administrativa de uma província não é falar sobre tudo o que é diversidade, tudo que é riqueza da província, os ritos de iniciação, a música, a constituição étnica, escamoteia-se essa parte, vamos para a $4^{\text {a }}$ classe, vamos para a $5^{a}$ classe, o que é que a gente aprende? É mais falando da África, é mais falando da Europa acima de tudo, do feudalismo, da colonização, do tráfico de escravos, então toda a nossa formação era baseada nisto, por isso, estudávamos mais a Europa, a Idade Média, a Idade Antiga Europeia em contato com o resto do mundo...

JH: Para completar o que Paka estava a dizer: é verdade que muitas pessoas são formadas em história, mas estes têm maior domínio da história europeia do que da história local, porque os conteúdos mais ensinados são os da história europeia.

\section{Tanto no ensino básico quanto na universidade?}

PM: Eu ia chegar aí. Durante toda a nossa formação, são 12 anos até a $12^{\text {a }}$ classe, em nosso nível, até o terceiro ano, a formação em história era mais voltada para a Europa, para as viagens de navegação, a revolução industrial, a busca do caminho marítimo para a Índia, coisas assim... Mas quando a gente vai para a universidade - o Júlio é meu contemporâneo nesta caminhada, vamos juntos para a universidade -, nos espantamos em encontrar a história de Angola, e também no último ano médio é quando falávamos do caso da Santa Maria, das guerras da independência, mas o que quer dizer, voltamos a falar da colonização, de lutas de emancipação, de personagens africanas como Bourguiba, Ben Bella, Houphouët-Boigny, Agostinho Neto e Amilcar Cabral, entre outros. Pulávamos dessa fase emancipatória que é da afirmação da OUA, e caíamos para a história de Angola, mas aqui, o protagonismo e o cerne da discussão é sempre o MPLA, descartando as contribuições da UNITA, descartando a contribuição da UPA, da UPNA, a contribuição da FNLA e de outros, 
até mesmo da FLEC que até hoje reclama sobre o caso de Cabinda. Está lá, nos anos 60 já reivindicava sobre a questão da luta da emancipação da independência e de Cabinda, e a gente chega à universidade e dá de cara com uma história de Angola repleta de conhecimentos, repleta de acontecimentos, uma riqueza enorme, só que tínhamos que ver aquilo, História de Angola I, História de Angola II, então em 2 anos você estudava. Nós temos problemas até de periodizar a história de Angola, fala-se de etapas, fala-se "vamos seguir o modelo europeu".

Essa Lei número 13 de 2001, de 31 de dezembro de 2001, essa é a lei que transformou o processo de ensino e aprendizagem em Angola. Com essa lei, a gente viu um currículo mais moderado para o ensino da história de Angola, principalmente para o ensino em geral, até quando eu saí ou deixei de dar aulas no ensino médio, não tínhamos concebido um programa muito bem preparado para escola de formação de professores. Nós tínhamos lá no município de Belize, no interior da província, o ensino médio com o ensino geral e a formação de professores, onde eu mais trabalhei. Mesmo o currículo todo do médio era mais a introdução da história geral, depois entrar para a história da antiguidade, na $11^{\text {a }}$ vai falar sobre história brasileira, na $11^{\text {a }}$ história da Idade Média e da Idade Moderna, na 12a fala da História Contemporânea e acabou.

Paka, você tocou em um ponto que também está no nosso roteiro, que é pensar o seguinte: aqui no Brasil a gente tem um problema muito grande na formação de professores, tenta-se sempre reformar o currículo pensando no problema da distância que se tem entre teoria e prática, muitas vezes se aprende na academia e, quando se chega à sala de aula, não se consegue ter uma desenvoltura, ou uma aplicabilidade muito tranquila desses conhecimentos. Eu queria perguntar para vocês se esse movimento também ocorre lá, essa dificuldade na formação docente, essa articulação entre teoria e prática. E, além disso, outro ponto que vocês levantaram, falando sobre a Universidade Onze de Novembro, vocês passaram por ela, certo?

PM: Não, nós passamos pela Universidade Agostinho Neto. A Universidade Onze de Novembro surge nessa questão de redimensionamento da rede pública do ensino superior. Então em 2009 há esse redimensionamento, e a Universidade Agostinho Neto, que era a única e com vários centros ou polos 
universitários em algumas partes de Angola, eleva esses centros e se criam algumas regiões acadêmicas com mais seis novas universidades, fazem o total de sete. Então a partir de 2009 nós passamos a fazer parte da Região Acadêmica 3, com a Universidade Onze de Novembro, e essa universidade está nesta região da província do Zaire e da província de Cabinda.

Então hoje, o ensino, ou melhor, a formação docente, a formação de professores, está disseminada em várias universidades dentro de Angola? Como é essa dinâmica?

PM: Precisamente para a formação docente em Angola temos uma ONG que tem nos ajudado bastante neste aspecto, que é a ADPP (Ajuda de Povo para Povo), uma ajuda filantrópica do governo dinamarquês. A ONG ADPP tem um plano de formação que cria a chamada "Professores do Futuro"; então, quando o aluno vai ao $9^{\circ}$ ano escolar e depois faz a $10^{\text {a }}$ classe em qualquer escola de ensino médio, recebe uma declaração de conclusão da $10^{\mathrm{a}}$ classe, que lhe permite se inscrever na ADPP. E ficam lá internados, onde recebem uma formação pedagógica, especificadamente como professores para as comunidades rurais, especificamente para o ensino fundamental.

O governo angolano tem o que chamávamos antigamente como Instituto Médio de Educação, hoje, Escola de Formação de Professores. Aí é onde a gente forma professores para o ensino geral. Nós em Cabinda, inicialmente, formávamos em três vertentes, ou seja, em três especialidades no ensino médio: Bioquímico (Biologia e Química), Mat-físico (Matemática e Física) e Geohistória (Geografia e História).

Então esse professor que era formado em geografia e história estaria habilitado, depois de um período de estágio e de práticas, e depois passaria a trabalhar para o Estado, mediante a aprovação em concurso público, dando aulas práticas nas comunidades, ou para dar aulas de história ou de geografia, e uma disciplina paralela à de geo-história.

Durante a formação, a queda ou inclinação da formação em que você mais se identificar é aquela que normalmente a pessoa quer ser. E também por causa do passado, em que havia às vezes um determinado número de formação de um curso, que não colmatava aquilo que era exigência do próprio Estado, mas 
uma área em que se é obrigado a dar aula, mas ao contrário, nós não tínhamos, só temos há pouco tempo um curso da língua portuguesa, um curso de formação de matemática, fazer desenhos técnicos.

E também os professores que eram habilitados em matemática ou física podiam dar formação politécnica, educação visual e plástica. Os professores de história e de geografia, às vezes podiam pegar educação moral e cívica, que damos às crianças no seminário, e podiam dar língua portuguesa, essas que eram igualadas com as ciências sociais e humanas.

E há uma pergunta que o Luciano fez e que me fez recordar de um aluno, onde eu falava para eles sobre as guerras mundiais. Cheio de dúvidas, um deles questionou-me assim: "mas professor, por que é que tenho que aprender de Guerra Mundial se não tem nenhuma ligação com a minha vida aqui no interior, aqui no Belize?".

Na verdade, eles queriam que eu explicasse como surgiu Belize. Como é que Belize se tornou um município? Como é que essa Angola constitui-se? O que seria muito bom.

Nós temos lá [em Angola] um plano curricular, e é bem rígido, nós temos um Ministério da Educação, e dentro do Ministério da Educação, temos um órgão cuja ação é como se fosse um verdadeiro policiamento, que é a inspeção escolar. Lá se considera e se segue à letra tudo o que está no papel, se for o caso de se verificar, se foi cumprido ou não o programa; faz-se até a verificação a partir do caderno do aluno.

E olha que depois passamos por certas circunstâncias até constrangedoras, onde o professor está a dar aulas fazendo adaptações do programa que ele recebe da direção da escola, e que a direção da escola recebeu do Secretaria ou do Ministério. Mas no final, quem elabora as provas é a Secretaria provincial da Educação! O professor que está em sala de aula e que conferiu com os alunos o grau das dificuldades e da forma que ele foi prontificando e dosificando o conteúdo, não é tido nem achado, muitas das vezes, nos enunciados das provas a serem aplicadas. São cinco questões, por exemplo. Dessas cinco questões, o aluno só viu naquele ano letivo a matéria correspondente a uma dessas questões. Eram constrangimentos enormes. 


\section{É uma prova anual?}

PM: Até que não, eram mais provas em série. Mas é que as provas finais e os exames de cada fim do ano letivo vinham sempre da Secretaria provincial da Educação. Diferentemente daqueles aplicados e realizados no sistema do Congo Belga - atual República Democrática do Congo - e alguns povos francófonos que têm algo que vou fazer uma adaptação literária e chamar de "exames estaduais". Quer dizer que é a partir da nacional que todo mundo, na mesma hora e no mesmo dia, realiza a mesma prova. O que não é o nosso caso, onde se elaboravam várias provas e iam diferenciando de escola para escola. Essa discrepância e confusão tem já a ver com as questões de organização administrativas.

JH: gostaria de fazer aqui um acréscimo, é importante falar sobre teoria e prática. Muitas pessoas são formadas e acabam não dando conta daquilo que são os conteúdos que absorvem enquanto professores. Houve muitos problemas na questão da colocação de professores durante muito tempo, e são professores que faziam matemática/física, mas por falta de vaga, por exemplo na história, ele pegava a cadeira ou a disciplina de história e ia lecionar, e com isso apresentava sérias dificuldades na transmissão de conhecimentos, o que fazia com que determinados alunos saíssem debilitados na sua formação. Uns desses até diziam para mim: "não tenho paixão pela história, porque o professor para além de não se formar naquela área não viu as metodologias de ensino de história etc. etc.”, o que de certo modo dificultava a transmissão de conteúdo. Com a reforma educativa que está em curso no país, hoje a figura do professor é um bocadinho mais valorizada, porque há 10 anos atrás ninguém queria ser professor em Angola. Havia pessoas que se formavam como professores e preferiam trabalhar noutras empresas que pagavam melhor, e hoje é o contrário, o governo angolano tem vindo a valorizar a figura do professor sobre tudo, nas condições de vida, nas condições salariais do professor, e há um regresso das pessoas que foram para o ensino, e nessa vertente o próprio Ministério de tutela, que é o Ministério da Educação, tem vindo agora a trabalhar para que se possam colocar os homens no seu devido lugar. Você fez história e vai lecionar a cadeira de história, fez matemática e vai aplicar a matemática, são essas transformações que vamos vivendo, fruto das grandes transformações que ocorrem no país. 
PM: Estamos a ser um bocado egoístas, pois que antes de começar com este diálogo, era bom falar desses dias. Estamos no dia 22 de novembro, que é o do educador, o dia do professor angolano, e o tema chega mesmo a calhar, pois é importante frisar isso.

JH: E quando falo de condições, não é só nas condições financeiras. Hoje Angola, do ponto de vista de construção de infraestruturas escolares, está a dar passos bastantes significativos, escolas que causam admiração do ponto de vista estrutural, enormes, com condições, modernas.

PM: É preciso assumir-se aqui, nesta parte, que desde 2002 há que se reconhecer o grande esforço do governo angolano no sentido de melhorar as condições, por causa do slogan que criou, de que "não pode haver criança fora do sistema de ensino, o ensino agora é gratuito". Então o governo estendeu o ensino até as áreas mais recônditas, mais longínquas do país - hoje há pelo menos uma escola de pelo menos três salas. Antigamente, uns 10 anos atrás, havia escolas em que estudávamos em pé, sentados em latas ou bancos e às vezes no chão, cada um trazia o seu banquito de casa, hoje não, hoje temos que reconhecer.

E aliado a esse esforço do governo angolano, também temos que dizer que hoje precisa-se conservar o que já existe; para mim, falta essa consciencialização da sociedade em reconhecer que o bem (patrimônio) está aí, e que é preciso ser conservado para as gerações vindouras; nós, que passamos em salas sem carteiras, sabemos o que é isso, chegar aqui e cada um ter aqui a sua carteira. Também queria voltar aqui no período de um tempo atrás, no qual se fez já uma pronunciação.

Aqui vou me ater ao artigo primeiro dessa Lei 13, que diz assim: "a educação se constitui num processo que visa preparar o indivíduo para as exigências da vida política, econômica e social do país, e que se desenvolva na convivência humana, no círculo familiar, nas relações de trabalho, nas instituições de ensino e investigação científicas e técnicas, nos órgãos de comunicação social, nas organizações tributárias, nas organizações filantrópicas e religiosas e através de manifestações culturais, e gimnoesportivas". 
Aqui, já há a disposição legal, fala-se das manifestações culturais ou práticas culturais, está aí patente, mas na realidade o que existe é falta de vontade. Nós ainda temos que preparar o homem para depois recorremos às diversidades de práticas culturais e também podemos dizer práticas educativas nas várias vertentes. O sistema de educação visa ou tende à formação harmoniosa e integral do indivíduo com vistas à construção de uma sociedade livre, democrática, de paz e progresso social.

A tendência do homem angolano, ou do professor de Angola, é de formar o homem crítico na sociedade, aliás, esse é um dos papéis. Quando falávamos do ensino de história, é esse ensino crítico, pensar criticamente a sociedade, mas quando pensamos muito criticamente como historiadores, somos olhados ou vistos como fomentadores de revoluções ou manifestações, mas é isso.

JH: Mas é preciso mais do que os programas, partir para a prática, muitas vezes escreve-se tão bem, mas é preciso passar para a prática.

Vocês tocaram no ponto da remuneração, hoje um aquecimento da procura da profissão docente. Aqui no Brasil passamos por um movimento inverso, de desvalorização, de perda do valor simbólico, do que é ser professor, dessa formação profissional, e coisas dessa natureza. Outra característica forte no Brasil contemporâneo seria uma marca da feminização da profissão docente, hoje nós temos um número bem maior de mulheres que se formam para a carreira de professora do que homens. Isso acontece em Angola? Como é essa divisão de gêneros? Como ocorre na profissão docente em Angola?

PM: Como Júlio disse bem, houve um período de fuga massiva de quadros formados na docência para outros ramos profissionais; com isso, duas profissões foram relegadas para a prática dos que menos tinham ou podiam, que é a enfermagem ou a saúde e o professorado. Depois se chegou ao momento em que tudo que era ruim, ruim em Angola, era do professor. Por exemplo, havia um tipo de feijão que levava quase um dia para cozer, que dizer que era considerado o "feijão do professor", havia também determinadas latas de leite. Aliás, professores há que o seu salário nem chegava para comprar umas calças jeans; então as pessoas já imaginavam, "sou pai de família, tenho esposa e filhos, com o meu salário não dá para sustentá-los”, faltava criar-lhes melhores condições. E onde temos famílias em que as mulheres dependem totalmente 
do salário do marido, mulher há que sabia que com o salário do seu marido não dava para sustentar a casa, e ficava o sentimento deste satisfazer os desejos dela, enquanto profissional.

Com essa tendência e essa valorização que também não é um mar de rosas, houve uma mudança qualitativa, há um retrocesso das pessoas. Imagina que nos anos 90, muitos de nós éramos convidados a dar aula, um diretor de uma escola achou que você tem capacidade disto ou daquilo. Convidava-te, "ó Paka, Luciano, Júlio, na minha escola tem falta professor, por favor, vamos, lá dar aulas!" E muitos respondiam: "Professor? Quem vai dar aulas? Ser professor ou dar aulas para quê?” Então era professor aqui, professor acolá, não é isso. Mas hoje, vou dar exemplo, com o IMNE, ${ }^{1}$ com a ADPP 2 e com o ISCED, que é o Instituto Superior de Ciências da Educação, há mais quadros. Imagina quem em Cabinda às vezes só são recrutados por ano cerca de cem, duzentos ou trezentos, e que são admitidos como professores, mas há ou se deu uma candidatura de cerca 4 a 6 mil candidatos ao professorado. O porquê disso? Porque há condições melhores. Hoje, tanto homens quanto mulheres se empenham nessas funções, interessam-se pelo professorado. Acho que a educação mais feminina é o ensino primário, são as pacíficas, mais pacientes, embora pese haver também muitos homens nesse nível. A destacar esse novo projeto, de educadoras sociais para as creches, aí temos a parte mais feminina.

JH: As mulheres sempre jogaram o papel fundamental na vida da nação angolana, quando os rapazes eram obrigados a irem à guerra, a ir à frente de combate, vestir farda para lutar, as senhoras é que muitas delas desempenharam o papel de professoras e educadoras. E eu me recordo porque sou de meados dos anos 70, grande parte das pessoas que davam aulas eram senhoras, porque os homens, não é que não poderiam dar, por causa da situação política não era possível porque as pessoas estavam sempre em fuga, muitas vezes as pessoas eram apreendidas aí nas suas zonas de origem e eram transferidas a outras províncias mais longínquas, então as mulheres, durante muito tempo foram elas que asseguraram a educação. Mas com a paz, com esse êxodo das pessoas na educação, podemos dizer que está tudo mais equilibrado, talvez na questão do ensino de base é bem maior a representatividade das mulheres. 
PM: Isso também é uma questão político-estratégica, porque o governo angolano criou a política de educação pública. Em vários setores deu-se espaço à mulher, então, quando a mulher angolana ficou consciente, em vários níveis, com o homem, da mesma forma que os homens retornam para a educação, as mulheres vão ocupando outras esferas, que antigamente eram somente lugar do trabalhador, temos $40 \%$ das atividades de mulheres na vida pública, hoje não há uma predominância de gênero em determinadas profissões.

O que é importante também para atualizar, é voltar àquilo que é nossa Lei de base. Se é importante falar aqui das escalonadas desse ensino, a educação é um sistema unificado, todo unificado, como aliás o próprio país também unificado é um sistema centralizado unificado, unitário como chamamos. Então temos os subsistemas de ensino, temos o subsistema de educação profissional, subsistema de ensino geral, que vai do pré-escolar até a $12^{\text {a }}$ classe...

\section{Qual a idade das crianças?}

PM: Hoje as crianças começam a entrar no pré-escolar. Este está subdividido em creche, de 1 a 3 anos, e jardim infantil, de 4 e 5 anos. $O$ ensino geral começa com a primeira classe, com 6 ou 7 anos. Neste temos o ensino primário, que vai dos 6 anos aos 11 anos, depois o ensino secundário, com o I ciclo de 12 a 14 anos e o II ciclo de 15 a 18 anos, respectivamente. São estruturas novas, a inserção e a obrigatoriedade do pré-escolar e do jardim de infância, que pela demanda de população angolana essa estrutura carece de espaços, está até entregue muitas das vezes a iniciativas particulares ou privadas.

Nós temos um ensino geral e temos o ensino técnico profissional, onde formamos técnicos básicos em economia, técnicos básicos em informática, em enfermagem, em eletricidade e outros cursos que vão surgindo. Depois temos o ensino médio, onde temos 3 subsistemas, que é o ensino geral, que chamamos de pré-universitário, temos os técnicos profissionais e a formação de professores.

E ainda temos um subsistema de ensino de adultos. Por causa da guerra muitos não tiveram oportunidades de estudar, mesmo antes tínhamos os marginalizados, que não podiam se juntar com os jovens, com adolescentes. É o 
chamado "sistema de adultos", é uma especificidade, aqui chamado de EJA, nós chamamos de sistema de adultos.

Aliado a esse subsistema de adultos nós temos outro, que é o sistema do ensino superior, aí já há diversidade de ramificação de licenciaturas. O sistema de educação tem esses três níveis de distinção - o primário, o secundário e o superior. Resumidamente, é mais ou menos esta a estrutura do contexto da nossa educação.

Passando um pouco para questões sobre o ensino de história e diversidade, $e$ patrimônio e tal. Vocês falaram do currículo geral, não necessariamente o currículo de história. Pensando no currículo de história, uma questão que acho relevante seria pensar também como esse passado colonial vem sendo tratado hoje no ensino de história, nos livros, nos livros didáticos ou mesmo nesse programa, porque existe um programa a ser cumprido vindo do Ministério da Educação. Como esse passado colonial - esse tempo de ocupação e de colonização portuguesa -, como ele vem sendo tratado nesses materiais, nessa legislação, hoje?

JH: No meu caso, eu trabalho numa escola do ensino médio, e na primeira classe do ensino médio nós falamos muito mesmo na questão da história de Angola. E a história de Angola é vista muito nessa vertente, nós procuramos fazer uma narrativa desse primeiro momento em que os portugueses chegam a Angola, isto é, em 1482, quando Diogo Cão chega à foz do rio Zaire, onde vão se manter os primeiros contatos comerciais com o povo conguês, e a partir do momento em que os portugueses começam com tráfico e passam a desenvolver a mesma atividade, a posterior, por via da força. Iam a aldeias, a zonas angolanas onde faziam guerras contra povos autóctones, submetiam esses povos à dominação. Há quem diga que foram os melhores homens que a África teve os que vieram parar nas Américas. Então, essa questão é tratada ainda com muita responsabilidade, porque entendemos que para se entender a história de Angola hoje temos de passar necessariamente por aí, e procuramos demonstrar como foi sobretudo o processo de colonização em Angola. Ao contrário de Cabinda, que é a região de onde viemos, onde a colonização durou 80/90 anos, noutra parte do país foram mais de 4 séculos de colonização, foi muito tempo, e o processo de colonização foi sentido em carne e osso - uso o termo, 
sobretudo, pelas práticas que os colonizadores infringiam nesse processo. Nós temos estado a entabular conversas com os nossos alunos nesta vertente, focando por exemplo como a colonização se processava em Angola. Nessa altura existiam duas classes na colonização portuguesa, uma que era a chamada "classe indígena”, que eram aqueles indivíduos que não sabiam ler nem escrever e que eram obrigados a uma exploração extrema, e outros que eram denominados de "assimilados", eram os indivíduos angolanos que por alguma razão já tinham atingido $4^{\text {a }}$ classe, que era a classe máxima, já exerciam uma profissão de respeito no seio da sociedade colonial, já falavam e escreviam bem o português. Esses, inclusive, já tinham um bilhete de cidadão português, mas para os outros, indígenas, os bilhetes vinham com cauda.

Nós temos vindo trabalhar muito neste aspecto: desde o primeiro momento em que os portugueses chegam a Angola, das lutas que os vários reinos que compõem hoje o território de Angola foram travando contra a presença portuguesa nas suas regiões, até o processo de formação dos movimentos de libertação que vão lutar para a independência de Angola, que acontece a 11 de novembro de 1975. Portanto é uma trajetória longa que temos vindo a fazer sobre o processo da história colonial, porque achamos que é fundamental fazer esses estudos, aliás, a própria história de Angola tem uma certa periodização, e é dentro desses períodos que nós vamos trabalhando, nas diferentes classes e nos diferentes níveis.

Pensamos que a história de Angola, nos dias que correm, deve agregar novos elementos se tivermos em conta o grande mosaico de culturas que conformam o território angolano. Julgamos que há toda uma necessidade de se fazer uma história nova para os Angolanos, que não atenda somente ao percurso histórico dos movimentos anticolonialistas que se destacaram na luta para uma Angola independente, embora seja uma realidade que pode encontrar novos espaços de integração do povo angolano no contexto universal, sendo um fator que nos remeteria a pensar na trajetória do país, evidenciando-se as conquistas alcançadas desde 2002, com o surgimento da paz.

Muito mais do que isso, defendo a construção de uma história de Angola, que assente suas bases nas transformações sociais, econômicas, políticas e culturais que ocorrem no país. E falando de transformações culturais, julgo ser 
importante, incorporar à nossa história a questão do patrimônio histórico-cultural, trazendo outras dimensões dessa temática que vai além do patrimônio de pedra e cal que muito se aborda, até mesmo em relação às políticas de preservação e conservação que têm sido utilizadas pelos órgãos que tutelam esses bens em Angola. Defendo uma política nesse nível, que vá ao encontro da imaterialidade do patrimônio.

Angola é potencialmente rico nas suas tradições, usos e costumes. Trabalhar sobre essas questões seria sem dúvida alguma enriquecer e reconstruir a história de Angola para as gerações presentes e futuras, mas é importante que haja maior abertura das instituições do Estado para essa causa que considero justa para um país que começa a dar passos muito grandes no concerto das nações.

PM: Devo referir aqui que Angola é um país novo e, com ela, muita coisa está se erguendo. A história de Angola é uma história que ainda estamos a tecer, estamos a construir essa história com todas outras contribuições, ainda que de forma tímida. As contribuições de cada um de nós, que fazemos pesquisa em história. E também na medida em que vamos desenvolvendo estas pesquisas, vamos democratizá-la.

Dentro do Ministério de Educação existe um órgão que é o INIDE, o Instituto Nacional de Investigação e Desenvolvimento da Educação, que tem seus colaboradores, tem seus assessores, que trabalham nos programas curriculares e, de certa forma, criam alguns manuais. Mas se nós repararmos muitos dos nossos manuais usados na Reforma Educativa, são meros efeitos de "copy and paste”, ou seja, têm sido cópias de manuais antigos ou de manuais portugueses. Já a história abordada no segundo ciclo tem sido um pouco diferente. Mas o que tem acontecido? Da mesma forma que há mais abertura para se tratar das coisas sobre Angola, da mesma forma há a carência de materiais. Por que essa carência de material? Porque durante muito tempo em Angola, e até um bocado hoje, não se permitiu escrever a verdadeira história de Angola. Ela está surgindo hoje, para a qual vamos realizando buscas aqui, investigações acolá, publicações aqui, é assim que estamos a tecer ou a produzir o pouco material ou manuais que trazem ou surgem com alguma coisa sobre a real história de Angola. 
Vou fazer uma panorâmica começando com os objetivos gerais da história no segundo ciclo do ensino secundário: aprofundar os conhecimentos adquiridos nos ciclos anteriores; durante muito tempo do ensino dos anos anteriores se aprendeu mais sobre a América e a Europa. Só que, quando chega para o segundo ciclo, o aluno tem de lidar com essa profundidade de conhecimentos sobre a história de Angola e sobre a qual nunca tivera nenhum conhecimento; neste ciclo é um pouco mais profunda a questão da história de Angola. E quando nós falamos da $10^{\text {a }}$ classe, os seus objetivos nos dizem: desenvolver o pensamento lógico e abstrato, compreender potencialidades antropológicas e culturais, reconhecer a complementaridade das perspectivas diacrônicas e sincrônicas na análise histórica.

$\mathrm{Na} 10^{\mathrm{a}}$ classe, nós passamos para aquilo que é periodização, conceptualização, classificação das fontes, começando com a antiguidade, depois falamos da África como berço da humanidade, aí nós tocamos na questão dos primeiros reinos africanos, fazemos uma panorâmica desses impérios da África ocidental sudanesa (Ghana, Mali, Songhai e outros), passamos para a África Central até atingir aquele que chamamos - e assim deve ser considerado - como um dos maiores, o grande reino que surge nos meados dos séculos XI, XII e XIII, pela sua maioridade, pela sua abrangência, até pela sua organização política, estratégica e econômica, que é o Reino do Congo, e nesse momento abordam-se os primeiros contatos dos portugueses com Reino do Congo. O que se verifica é que levamos essa discussão quase em toda a $10^{\text {a }}$ classe.

$\mathrm{Na} 10^{\mathrm{a}}$ e $11^{\mathrm{a}}$ é que se começa a abordar os primeiros contatos, ou seja, a abertura da África com o Atlântico; então já começamos a ter essa presença da história europeia, mais uma vez nos nossos manuais do segundo ciclo. Daí observamos, e bem patentes, os primeiros contatos, estão aí as revoltas, as resistências pegam a matéria do segundo ano que é a 11 ${ }^{\mathrm{a}}$. E curiosamente, na $11^{a}$ começamos o tráfico transatlântico, as punições do tráfico de escravos, as reformas da Inglaterra, a proibição do tráfico no Brasil, o grito do Ipiranga com a proclamação de independência do Brasil, que vai ser um marco importante para o fim e a abolição da escravatura nas colônias portuguesas da África. A criação por parte de Portugal em África dos “novos Brasis”, Portugal era um império que ao perder a sua joia, que é o Brasil, vira suas baterias ou os seus interesses para Angola e Moçambique. Então sempre falamos dessa trajetória, 
falamos da conferência de Berlim que é essa partilha, falamos das possessões europeias em África, falamos da questão da consciência negro-africana, das lutas de libertação nacional, o pan-africanismo, a OUA, e desta perspectiva fazemos uma panorâmica geral, demonstrando essa ligação África-Europa.

A $12^{\text {a }}$ classe tem três unidades ou, como quisermos chamar, três capítulos. No primeiro capítulo falamos da África Austral na segunda metade do século XX, ou seja, no último quartel do século XX, isto é, entre 1975 e 90 . Aí vamos falar da integração econômica e regional de Angola em seu espaço regional, alianças e cooperação econômica e política, com destaque à SADC [Comunidade para o Desenvolvimento dos Países da África Austral], a extinta OUA, Organização de Unidade Africana, hoje UA, União Afriacana. No segundo, “Angola: de 1975 à atualidade”, aborda-se a questão das lutas de libertação nacional, a proclamação da independência, a guerra civil, as várias resoluções e tentativas de negociação para a paz. E no terceiro capítulo trabalha-se sobre os problemas da África Austral de hoje.

JH: Aí vai envolver esses três movimentos, esses três partidos - o MPLA, a UNITA e a FNLA - durante a Guerra Fria, em que o mundo estava vivendo dois opostos, onde os Estados Unidos estavam de um lado e União Soviética de outro.

PM: E aí falamos da expressão "independência”. A ideologia tomada foi o marxismo-leninismo, com a criação de um sistema do partido único.

JH: Falamos das primeiras eleições individuais em 1992, do fracasso dessas eleições.

PM: Nesse período, também falamos da economia planificada em Angola, essa noção de que Angola vira todas as baterias para seu desenvolvimento, sobretudo sobre a produção do petróleo, esquecendo-se das demais riquezas do país, e essa abertura ao capitalismo, a partir de 1989-1991. Realizam-se as eleições gerais livres e diretas e o subsequente retorno à guerra. E na história mais recente de Angola se destaca a ajuda que Angola dá para a questão e resolução de alguns problemas da região, através e nos Acordos de Nova York. Há uma atuação de Angola que foi preponderante para a queda do apartheid na África do Sul, assim como para a independência da Namíbia. Fazendo-se valer as 
palavras de Antônio Agostinho Neto, de que "Angola será uma trincheira firme para a revolução dos povos oprimidos em África”, essa história funciona, é o sentimento nacional e o orgulho da nacionalidade angolana.

JH: Para mim, nessas três classes, apaixona-me mais trabalhar com a $12^{\mathrm{a}}$, por causa desses elementos novos que traz, uma história muito recente, apesar daquela questão que sempre falamos em classe, acontece muita coisa a favor de um determinado partido.

Como funciona em Angola a oferta de livros didáticos para as escolas? É o governo que produz, a iniciativa privada...? Os professores escolhem os livros, ou os livros já vem predefinidos?

PM: A lei é unificada, o sistema é unificado, esse $\operatorname{INIDE}^{3}$ que estávamos a dizer, que é o instituto do Ministério de Educação, é ele que se encarrega de todos os livros e manuais. Há uma verba do Estado locada para essa instituição, no sentido de pelo menos no ensino fundamental o livro ser de distribuição "gratuita”, entre aspas, para todas as escolas de todos os cantos do país, mas não há, por exemplo, a liberdade de criar dois modelos de livros e para que o professor possa escolher, não!

Acontece isso, normalmente, quando há confusões editoriais, muitas vezes fazem cópia, copy and paste de Portugal, por as editoras estarem também lá em Portugal, o fato é que recebem a encomenda e chegam a fazer no mesmo ano dois livros similares, e você percebe isso, uma ou outra diferença na capa, inclusive alguns cometem erros graves de conteúdos.

\section{E os autores são portugueses ou angolanos?}

PM: Há maior privilégio e credibilidade aos trabalhos de autores estrangeiros para produzirem livros didáticos em relação aos próprios nacionais; ultimamente é que se está dando credibilidade às produções dos Angolanos, mas há sempre aquele problema de se ver vestindo a camisola partidária. Mas no início se vê como uma obrigação, só que está aí o papel do Estado, como diz o colega Júlio, está decretado, "o INIDE produz", mas muitas das vezes antes de o livro chegar nas escolas já está na zunga, ${ }^{4}$ já está na quitandeira, ${ }^{5}$ no mercado informal. Também há graves problemas na questão da distribuição. Antigamente 
havia livrarias por quase todo o país; as livrarias foram transformadas em cantinas, em lojas ou roulotes, não há uma representatividade para a distribuição desses livros, dos cadernos e de outros materiais escolares. Temos na província de Benguela a Emateb, que produzia materiais didáticos e não se sabe se funciona até hoje ou não! É daí que o Ministério tira dessa província, neste caso Benguela, e leva para Luanda, de Luanda é quando se encaminha para as demais províncias e, às vezes, só chega no último trimestre - lembrando que temos três trimestres durante o ano letivo. Às vezes, quando o manual chega para ser distribuído para os alunos desse ano, este já passou de classe, mas todos os anos tem que se fazer essa distribuição. Na regra, os livros tinham de ser produzidos e revistos a cada 2 anos, se notassem muitos erros naquele livro já produzido. Mas isso não acontece, eles apenas vão reimprimindo, ou até mesmo reproduzem o mesmo livro. Só que antes de esse livro ser distribuído o aluno já está a concluir o segundo ou terceiro trimestre. No ensino médio, até nós mesmos e muitos dos professores não têm acesso ao livro, não seguem as mesmas tarefas pedagógicas nem o mesmo conteúdo, nós trabalhamos com cópias, às vezes um de nós por esforço próprio adquire e leva um manual de onde outros tantos somos chamados. Como em muitas vezes, a gente vai contribuir com dinheiro para que alguém possa viajar a Luanda a fim de encomendar livros, ou então acabamos fazendo xerox, fazemos cópias de todo ele, e temos aqueles professores que vão produzindo apostilas, vão complementando e subsidiam os alunos. Porque o nosso ensino também entre aspas é meio "bancário", o professor ainda é aquela pessoa detentora do saber, ele é quem traz o conteúdo e o tem depositado ao aluno. Se o material didático, o livro, chegasse ao aluno, o professor diria apenas "vamos abrir a página tal", "vamos abordar isso, fazer sua explanação", ou poderia até ter essa inciativa de propor temas abertos, "vamos fazer uma busca", recolhe e traz, ou tem a internet, que já tem ajudado. Mas, a verdade é que o livro não é o centro de uma discussão séria da educação angolana.

JH: Eu gostaria só de acrescer mais alguma coisa em relação a isso, na vertente do conteúdo. Às vezes há erros muito graves e crassos com o conteúdo, e o professor, se não estiver atento, acaba passando para os alunos aquilo que não é o ideal. Como algumas temáticas são superficialmente ensinadas, no caso por exemplo do patrimônio histórico - e no meu caso, que me apaixonei por essa temática há coisa de 3 ou 4 anos -, sempre que se fala de Cabinda o conteúdo 
é muito superficial. Com alguma experiência que fomos acumulando durante esse período, procuramos buscar outras fontes que agregam para poder dar a conhecer a verdadeira história de Cabinda, como é que esses patrimônios surgiram, qual é a importância que têm, então os alunos ficam mais interesses em saber com alguma profundidade as questões patrimoniais.

PM: Na 11 a fala-se de Cabinda parece que em uma só semana ou lição, já se fala tudo sobre Cabinda. Vou tocar nesse aspecto, mas vou usar da minha particularidade: até entrar na universidade, não tinha visitado um museu. Essa interação que é vista aqui, a escola no espaço cultural, no espaço social, momentos de sítio. Ontem estávamos no museu da PUC-Minas, encontramos dois ou três grupos de escolas diferentes, já na tenra idade se tem esse contato, que alguns não tinham, é bom isso, os espaços livres, tudo isso caindo na questão da instituição escolar.

Se você pega os alunos e põe os alunos lá fora, assim, e cria um debate, o inspetor pode até chegar a aceitar sem problema nenhum, mas se voltar na segunda vez, esse inspetor controlará a partir dos alunos, ou seja, se estes não escreveram nada; se escreveram, vai ter que olhar para o plano de aula, para conferir ou averiguar. Se o professor não usa o plano de aula, ou se o tema abordado não tem nada a ver com o currículo, e se no dia seguinte o professor tornar a sair com os alunos para fazer visita, o professor vai ser conotado como aquele que não trabalha, "esse nunca deu aula".

JH: eu falo dos próprios professores que não têm práticas patrimoniais. Os professores não visitam o patrimônio, e pensamos que seja uma questão de cultura, de hábito, a própria população não visita, até as pessoas que moram próximo a esses sítios não vão, as pessoas não vão ao museu, não fazem nada, eu trago essa questão para problematizar.

Como funciona essa dinâmica do patrimônio cultural em Cabinda e Angola de forma geral? Porque parece haver uma tensão aí. Por exemplo, um sítio arquitetônico é tombado pelo governo, mas não há uma recepção pública no sentido de abraçar esse patrimônio como sendo seu. Estou correto nesse sentido? Como funciona essa tensão, pensando aí os museus, os arquivos que são possibilidades do trabalho do historiador e para o professor de história em Angola? 
PM: Vamos só fazer uma comparação entre Luanda e Cabinda. Luanda, por exemplo, pelo que eu conheço, tem uns três ou quatros museus, e a questão do tombamento em Luanda, como é que falamos lá em Angola? há as "classificadas", elas estão e são consideradas como lugares de lazer, lugares de excursões, lugares de debates juvenis, de escolas, na capital do país.

Quando voltas para Cabinda, só monumentos e sítios que interessam ao partido é que são classificados pelo governo. Vou dar para isso um exemplo. No início deste ano, no ISCED/Cabinda, nós, formados em História, no dia 25 de maio temos nos reunido com essa questão do dia da negritude, então trocamos experiências nos sítios que mais tenham impactos na história do povo africano. E sempre que a gente planeja, vem um veto da universidade, até mesmo dentro da universidade não nos é permitido. Ou seja, sempre que o Departamento de Ensino de História planeja uma atividade relativamente ao dia da consciência africana, dia da África, não é permitido, a atividade não sai, não se realiza. Por quê? É uma questão ideológica. Se o governo liberar esses espaços, classificar esses espaços todos, há aquele receio de que as pessoas vão questionar. É curioso que o Tratado de Simulambuco foi assinado quase no centro da cidade, o monumento está aí, mas está se deteriorando. Os jovens, por mais que criem associações, não podem entrar, porque não vamos poder criar uma campanha, por exemplo, de cultivar flores; ou vamos criar um ponto de debate em que o nosso centro de debate vai ser sobre o monumento ou sobre o Tratado de Simulambuco, chega a ser impensável dizer! Não se admite que as pessoas criem uma exposição sobre o tratado do Simulambuco, mas se aceita que se fale do local de concentração de escravos, porque não tem conotação ou não fere sensibilidade política. Desde logo, sobre o Tratado de Simulambuco, se um grupo de jovens ou um grupo de intelectuais vai ter a necessidade e o interesse de explicar o porquê desse tratado, o que significa o Tratado do Simulambuco na história de Cabinda, como surgiu, por que surgiu, aí já entra a questão da declaração e aceitação dos Cabindas à proteção da colonização portuguesa, depois separada do resto do território angolano.

Quanto ao museu que nós temos em Cabinda, é um museu sui generis, é um museu tout court, ou seja, como um todo, tem uma parte natural (ligada à natureza), tem uma parte do dia a dia, do cotidiano, é moderno, quer dizer, é tudo confinado naquele museu, mas é um espaço sem estrutura adequada, em 
termos de acesso. Não é o que podia ser, se imaginarmos a dimensão de um museu regional. E acho que são duas salas desta onde estamos, até no comprimento e na largura, pode ser um pouco mais.

JH: O Estado reconhece esses monumentos, mas as pessoas não se apropriam deles, inclusive existe uma lei que chamamos "lei patrimônio cultural", no seu artigo primeiro manifesta o seguinte: no ponto um, considera-se tarefa fundamental do Estado e dever dos cidadãos a proteção e valorização do Patrimônio Cultural; visam incentivar e assegurar o acesso a todos à fruição cultural; vivificar a identidade comum do povo angolano e fortalecer a consciência e a participação histórica do povo angolano em realidades culturais de âmbito regional e internacional; promover o bem-estar social e econômico e o desenvolvimento regional e local, defender a qualidade ambiental e paisagística. $\mathrm{O}$ ponto dois constitui objetivos primários da política cultural o conhecimento, a proteção, a valorização e o crescimento dos bens materiais e imateriais.

Isso está na lei, na realidade, mas na realidade não é isso que acontece, por quê? O Estado cria uma lei que mostra uma vontade de proteger esses bens, de valorizar esses bens. Mas o governo é a primeira instância que desvaloriza esses bens, porque, como é que você vai falar de valorização se você não protege esses monumentos, se você não divulga, não cria condições para as pessoas que queiram visitar? Um indivíduo que tentar fazer uma visita, que tenha alguma visibilidade, é cortado, então é o que dizemos naquele momento, existem, mas precisam ser particularizadas de fato.

PM: Acima de tudo, o que eu acho é o desmistificar, e a preocupação enquanto profissional e professor de história é a questão do coletivo, acho que o coletivo deve ter unidade. E enquanto se escamotear a verdade e essas realidades, enquanto não se levar a discussão aberta sobre essa diversidade, esses patrimônios, esses monumentos, e até uma aceitação disso como um direito, não vai se ter em conta os objetivos enunciados, quer pela lei quer pelos currículos. Logo, cabe a nós mudarmos isso e até pode não sermos nós a mudar isso hoje, mas o tempo dirá, e é dali, desses pontos e perspectivas, que vamos indo diversificar a formação do homem angolano. Vou dar exemplo: respeito muitas pessoas que estão dentro e que trabalham nos museus, mas há quem está lá no museu e não tem uma formação em museologia ou em museografia, ou coisa 
parecida. Quer dizer, acumulou experiência. Muitas vezes temos o Departamento ou a Secretaria Providencial da Cultura, e quem está lá não é um sociólogo, não é um antropólogo, não é um culturólogo, é alguém que por conveniências ou influências de A ou B, de sicrano ou beltrano, se colocou no lugar em que está, mas não possui qualificações exigíveis para exercer determinadas funções e atribuições. Então ele está na Secretaria mas não entende o que é isso, cultura.

São essas questões que temos no dia a dia, nós hoje temos ou nos debatemos sobre a questão das línguas nacionais, e a bom tom o governo angolano instituiu mecanismos, criou equipes de especialistas que estão a trabalhar e, em alguma províncias, vamos começar já nos próximos anos a experimentar o ensino das nossas línguas de matiz africana para acudir a questão do ensino bilíngue. Vão-se implementar incentivos para publicação de livros em línguas nacionais, gramáticas, dicionários, e vamos tentar isso. Temos que elogiar isso, mas internamente se faz necessário que essas discussões alcancem um âmbito público, com debates, e que todas as demais vozes se possam levantar e opinar. Poderiam ser, por exemplo, em uma rádio. Hoje pode-se usar internet para ouvir das pessoas “o que você acha deste ou daquele aspecto", mas é deveras muito complicado, é difícil não poder falar sobre isso.

Paka, você levantou uma questão que eu acho interessante, a respeito da aprendizagem histórica, que ela também não ocorre somente no espaço escolar, e até mesmo você, além de professor de história, é radialista também. Como se dá em Angola essa coisa que hoje a gente chama de "história pública", pensando aí em outras vozes que podem ser úteis ao ensino de história, a compreensão da aprendizagem histórica, pensando na radiodifusão em Angola? Como isso vem ocorrendo? Seu projeto também dialoga com isso ou é de outra natureza, com essa perspectiva?

JH: Em Angola eu faço programas de outra natureza, mas há 3 ou 4 anos atrás, quando eu me interessei sobre essa questão, foi o fato de eu ter ido a uma reportagem no dia 1 de fevereiro, que é exatamente o dia do Tratado de Simulambuco. As pessoas foram para lá, não para refletirem em torno do Tratado de Simulambuco, foram para fazer a abertura de 4 de fevereiro, que marca o início da luta armada de libertação nacional, que não tem nada a ver. 
E daí parte a minha vontade de abordar essa temática. A própria comunicação social, os meios de comunicação de massa, precisam de um processo de democratização.

PM: Eu até tenho uma outra visão. Acho que para entender Angola temos que partir do pressuposto: que tipo de Estado vigora, que tipo de governo há em Angola, em que os meios de comunicação de massa, os grandes jornais, a rádio, a televisão, é tudo pertença estatal. Estão aí mais para divulgar os nomes e interesses de quem está no poder; imagine que há bairros que podem ficar meses e meses sem água e sem luz, mas disso ninguém fala, e se fala, a informação é deturpada e a reportagem não sai com fluidez, passa à tangente.

Eu sempre partilhei de uma ideia, acho que como professor de história, posso me apropriar de sítios e monumentos para deles dizer sempre alguma coisa aos meus alunos e fazer deles um aprendizado. Aprendi a valorizar todas as oportunidades, pois aprendi: "até o relógio parado está certo duas vezes ao dia...", e que "ninguém é tão bom que não tenha nada a aprender, e ninguém é tão mau que não tenha nada para dar ou ensinar".

O que eu acho interessante é quando começamos as festividades, ou sempre que estamos nas vésperas do dia 1 de fevereiro, falamos já sobre a data de 4 de fevereiro, antecipando, ou uma semana antes, falamos do 4 de fevereiro. Eu gosto de transpor os limites estabelecidos por alguém, já falei isso aqui anteriormente, é questão de consciência. Se nós pegarmos os acontecimentos do Tratado do Simulambuco e transformá-lo, fazê-lo entender como uma vontade de consciência nacionalista, uma expressão do amor do cidadão à sua terra, que não a entrega de bandeja aos portugueses, mas que obriga os portugueses a assinar um pacto. Podemos relacionar esta consciência ao ato do 4 de fevereiro.

Eu posso fazer um discurso, onde começo no Tratado do Simulambuco e fecho com o 4 de fevereiro, e se a gente faz isso, tira aquela conotação de independentistas, e pseudoideia ou conotação de que algo está escondido. O que é importante aqui ressaltar é o nacionalismo, a conscientização de pertença ao território. Em 1 de fevereiro a gente entrega, mas não entrega com as mãos bandejadas. Entregamo-nos a um protetorado com alguns direitos reservados aos autores. E no 4 de fevereiro rompe-se com a dominação colonial 
portuguesa, para dizer que essa terra é nossa. Eu até passei por isso um dia, e na hora em que falei isso, chegou alguém para mim e falou assim: "convém você nem falar essa parte ou frase, deixa as coisas como estão"; e eu disse, então: com isso podemos nos apropriar de certas "coisas" que transmitem uma certa identidade para o aluno, mas tem uma história que poderia ser aproveitada e podia enriquecer a discussão histórica e um bom aprendizado.

Caminhando para o final da nossa conversa, pensando um pouco sobre ensino de história Brasil/Angola e pensando sobretudo em questões que a gente já discutiu em outros contextos, a respeito da obrigatoriedade relativamente recente do ensino da história africana, da história indígena, afro-brasileira, compreendendo aí essas histórias também no plural e não uma única história africana, uma única história indígena, afro-brasileira etc.: como vocês, profissionais de história e como pesquisadores da área da educação, da área de história, e também africanos, esse tempo que vocês estão aqui pesquisando, conhecendo a realidade educacional brasileira, como vocês estão vendo a obrigatoriedade desses conteúdos? O que vocês já conseguiram perceber de diálogo possível entre Brasil e Angola?

JH: Em primeiro lugar, em primeira instância, vamos fazer uma história da África aqui no Brasil. Mas, num primeiro contato, numa primeira conversa que tivemos com alguns professores que trabalham aqui com história, deram-nos a entender que a história da África que se ensina hoje no Brasil não tem nada a ver com, digamos, os grandes acontecimentos da história em África. Hoje tenta-se ensinar uma história da África no Brasil - que podemos chamar de romântica, que tentar escamotear, escamotear aquilo que o homem negro sofreu - e das suas grandes criações.

E é curioso que há coisa de um mês estávamos numa sala de aula com a professora Júnia Sales, que convidou alguns professores e acabou vindo só uma professora. Paka também interveio nessa questão, é extremamente instigante e frustrante quando as pessoas, e isso nós sentimos aqui, quando as pessoas continuam a valorizar aquilo que a África foi e continua a ser, quando eles falam que não se pode contar a história da África a partir das grandes criações, dos grandes impérios e reinos africanos que surgiram no século X, e Paka falou 
muito bem disso, os reinos do Mali, reino do Songhai, reino do Senegal, enfim, das grandes organizações políticas e administrativas.

Então, quando as pessoas dizem que falar dessa história é retomar a questão da pirâmide invertida, isso para nós, como historiadores e africanos jovens... Naquele dia, em uma sala de aula uma professora brasileira tentou falar isso para nós, eu e meu companheiro Paka quase choramos, por isso é que eu trouxe essa obra de [Leila] Leite Hernandez, África na sala de aula. Essa senhora faz aqui uma abordagem daquilo que o Paka esclareceu para essa professora. Então, primeiro não podemos ter a África como sendo um todo, que a África é um país com a mesma cultura, com a mesma língua, com as mesmas crenças. A África é um continente e grande, com uma diversidade cultural enorme, e cada espaço da África tem sua especificidade, tem suas culturas, tem suas línguas. Fazer um estudo da África como sendo um único país e uma África sem história! Porque durante muito tempo se passou essa ideia que a África não tem história, citavam o historiador francês que dizia "Afrique, un pays sans histoire”. Nós, historiadores e professores contemporâneos, não aceitamos isso, e voltamos a grandes africanos como Nkruame Nkruma, Leopold Senghor, enfim, grandes africanos que começaram a dar passos significativos e importantes para a reconstituição da história da África. Porque a história da África foi interrompida, e é necessário dizer que antes da ida dos europeus à África, naquele período nós vamos encontrar Estados africanos bem organizados, do ponto de vista político e econômico, uma estrutura social bem consolidada.

PM: A modo do Africano, não é?

JH: Imagina, a África viveu um período muito longo de interrupção de sua história. O que seria da África com aquela organização de 5 ou 6 séculos atrás, se não fosse interrompida? O que seria a África do ponto de vista de desenvolvimento? Então é preciso pensar nesse aspecto, e eu penso que aqui no Brasil continua-se a ensinar a história da África errada, é preciso partir dos pressupostos daquela história da África real. Não vamos minimizar a coisa, e eu não vi o currículo, mas por aqui, o que se fala que se ensina aqui é uma tendência de minimizar a coisa. Não se fala da África nesse sentido desses grandes impérios, não se fala do tráfico de escravos, ao meu entender eu penso que a história da África deve ser ensinada por aquilo que é, e deve ser ensinada como 
é. Agora, quando criamos estereótipos de uma nova história da África no sentido de não traumatizar quem vai estudar a história da África, não sei se estaríamos atingindo nossos objetivos. É preciso ensinar a história da África, e para entender a África temos que falar mesmo dessas grandes sociedades que surgiram naquele momento, não é um modelo eurocêntrico. Dizer que nós, africanos, é que estamos a tentar imitar os Europeus, não, porque muitos países europeus, naquela altura, não tinham a organização que a África já tinha há coisa de 5 ou 6 séculos. Então é preciso ensinar a África. E eu trago esse livro, você também pode fazer uma leitura.

\section{Essa é uma boa referência na sua análise?}

JH: É uma boa referência, até porque quem escreve sobre essa história não é um africano.

É um brasileiro. A historiografia brasileira foi ancorada preponderantemente na historiografia ocidental, sobretudo europeia, por exemplo, escola dos Annales, História cultural, História social Inglesa, o que teve um impacto muito grande na historiografia brasileira, e em alguma medida desdobramentos na história escolar feita no Brasil... Então falem-nos um pouco a esse respeito: o que se tem de historiografia contemporânea africana, angolana ou portuguesa? Principais temas, as fontes para história da África, quem está fazendo a história da África hoje ou história de Angola no continente africano?

PM: Primeiro, quero dizer sobre essa questão, sobre ensino de África e indígena, para dizer que o Brasil avança no tempo com essa iniciativa e que é interessante, vai abrir portas para o povo brasileiro começar a identificar-se e entender-se com o que é o brasileiro na sua essência do Brasil. Isso é que é importante, então a iniciativa é louvável, tem que ser aberta e tem que ser abraçada por todos que quiserem.

A África é, como disse o Júlio, “Afrique sans histoire”. Por que se defendeu que a África não tem história? Porque partiu-se do pressuposto de que a história é feita a partir da escrita. Ou seja, onde não há escrita, não há história. Esquecemse de que há várias fontes de história, há várias formas de o homem fazer história, e essa ideia se vinculou, e é nessa perspectiva que muitas pessoas europeus, americanos e até brasileiros -, apaixonados pela essência, muitas 
vezes pela excentricidade que achavam em África, escreveram de forma exótica sobre a África e de forma excêntrica.

Dou exemplo do colega Francisco Chocolate. Ao participar de uma palestra da professora Zoia Prestes sobre Vygotsky, na qual ela traz um novo olhar sobre os conceitos e o conhecimento que se tem sobre as teorias de Vygotsky, o Chocolate perguntou para a professora se era preciso anular os conhecimentos já adquiridos e se o que nós estudamos anteriormente perderia validade. Será que vamos botar fora? De tal sorte, e vale dizer, a produção brasileira, europeia e americana sobre a África é válida sob um ponto de vista... Dão sempre um olhar diferenciado, agora, o que é bom nos estudos africanos é que nós temos que pegar essas referências e fazer uma adequação, fazer uma equiparação com o que está sendo produzindo hoje em África, das mãos dos próprios africanos. Só que a questão da produção em África é muitas das vezes interrogada por uma única coisa, como bem falamos aqui do ponto de vista do material didático. Há algumas questões com as quais não concordamos, até os próprios Estados africanos acham, e dão mais credibilidade a investir para que um estrangeiro venha investigar algo em África e publicar do que investir em uma pesquisa de um próprio africano. Vou dar exemplo: em Cabinda tínhamos recebido um casal de nórdicos que pediram para fotografar as várias casas dessa cidade de Cabinda. Muita gente se interessou, prontificando-se em ajudá-los e apoiá-los, e eles foram fotografando. Por mais incrível que pareça, depois de um ano o casal voltou e ainda com o apoio do governo angolano, que os hospedou em hotel da cidade, o Hotel Maiombe.

Para muita gente era coisa insignificante, pois era um livro constituído só de fotografias; imaginemos nós, que seja um angolano a pedir apoio do governo angolano para que pudesse publicar um livro sobre retratos da cidade de Cabinda. Lhe garanto aqui que não haveria de ter apoio. Há muita gente - estudiosos e intelectuais - que escreve, mas não tem como produzir ou publicar os resultados de sua produção, e o Brasil sai em vantagem nesse aspecto. Brasil em geral, eu digo, Minas Gerais e a UFMG em particular.

Este convênio entre UON e UFMG, se for bem aproveitado de ambas as partes, nós queremos crer que sim e provar que, ao querermos nos formar, estaremos trazendo para cá outros olhares e contribuições sobre a África. Mas também a 
UFMG pode sair na dianteira em produzir livros escritos por pesquisadores africanos para falar sobre Angola e sobre a história da África, e a UFMG pode e muito bem, pelo peso que ela tem e representa no contexto do Brasil, dessa união que se tem entre Angola e o Brasil, desmistificar essa ideia que se tem de uma África una.

Então é importante isso. África produz mais ainda hoje, a sua produção é subvalorizada, se sente um pouco limitada e fragilizada pela concorrência do mundo capitalista ocidental, porque quem detém a prioridade de financiamento está lá fora. E o que está aqui dentro acha que quem está lá fora é melhor. Se porventura partir de um pesquisador angolano a ideia de propor algumas mudanças em termos de currículo, programas ao Executivo, não será bem-vinda ou de início aceite; veja que no INIDE, até um tempo atrás, a maior parte dos autores e assessores eram quase todos estrangeiros - sem desprimor aos estrangeiros -, mas tem muita gente produzindo, tem gente formada em história, em antropologia, linguista, ou em outras e várias áreas de saber. Mas se esse nacional vai e tenta dar um parecer... até a sua formação é questionada - questões como esse daqui: estudou mesmo? Estudou onde? Que competência tem ele? - e, desde logo, está o responsável ou dirigente público a propor que tem alguém aí - no estrangeiro, ou que lhe seja afim - e que ao ser chamado ou convidado, vai trazer a solução. Pense comigo, onde está o maior museu em termos de acervo sobre a África? Na Europa, em Berlim... Mas será que já se fez uma discussão a nível dos governos sobre a questão do retorno desse patrimônio da África para a África? Os dirigentes não estão interessados nisso, a própria União Africana (UA) devia debater sobre isso, mas não faz uma discussão acerca disso. Então falta muita seriedade e vontade política em África, e são essas questões que nós, paulatinamente, vamos ter que ultrapassar. O professor Cartelli, no museu da PUC Minas, onde efetuávamos uma visita, falou-nos nos seguintes termos: "vocês estão preparando em vosso país condições para que as novas gerações gozem do melhor que há em seu país daqui a 50 ou mais anos". Por isso devemos nos propor desafios, e o que eu acho que o ensino afro-brasileiro, na questão da identidade do povo brasileiro, trará de inovador e fundamental é a desmistificação da unicidade da África, no entender o que é África, assim como a antiguidade africana é importante, pois ela é rica em relatos. 
E essa produção contemporânea, hoje, ela é melindrada, é ofuscada pelos interesses políticos, e também quando o Júlio fala daquele debate que tivemos, foram até interessantes os pontos de vista apresentados, mas quando se inverte a pirâmide sobre a história da África, isso causa indignação, pois creio que o historiador deve proibir-se de julgar, não devemos julgar os méritos e deméritos de uma pessoa.

Temos de referir os nomes de Leopold Senghor, Kenniata, Nyerre, Nkruman, Hampate Bâ, Chek Anta Diop e outros. Devem ser - e porque o são - considerados como os grandes percursores e grandes paradigmas da ciência e da intelectualidade, quando de África nos queremos referir. Apesar de muitos destes, ao mesmo tempo em que se preocuparam em escrever, também tinham um lado político, o de garantir a liberdade do seu povo. Muitos afirmavam: "eu não posso deixar o povo sofrer, subjugado...”. Enfim, eles fizeram essa união ou dualidade, ninguém pode estudar a história da África somente usando as fontes africanistas, sem usar fontes ditas "africanas" por sua essência. Agora, quando alguém pega em um feito negativo de um africano, escritor africano, para fazer juízos, é complicado! A nossa intenção é ajudar naquilo que se produz por cá. Achamos que o Brasil caminha a um bom passo. Um exemplo são as parcerias que se tem criado, aqui mesmo na FaE tem um professor que pode não ser da FaE mas é da UFMG, ele perguntou, "você vem da África? Você conhece fulano?”. Respondi-lhe que sim, eu vinha da África, e que a África tem 54 países, E ele vem me perguntar se eu conheço o fulano! Ainda que me se tivesse dito de Angola, ou mesmo de Luanda, a minha pergunta seria, "mas de que parte de Angola?". E mesmo se fosse de Cabinda, mas às vezes eu nem conheço todas as pessoas em Cabinda. Insistentemente, me indagava o professor: "O cara é famoso por lá, e você não o conhece?” Famoso ... não sei no quê! Essa é a condição a que me expus, e delicadamente informei que sou Angolano. Só depois fez-me perceber a quem estava se referindo: “Ah, não.... ele é moçambicano. Mas você não conhece ele?”. E continuou na mesma tecla, parece ter sido alguém que tinha estudado cá, foi amigo dele e que se notabilizou por criar aqui momentos de diversão e farras, e por esse fato, ter granjeado nome neste espaço, supunha que também por lá explodiu de fama. Era preciso lhe dizer que Moçambique está no Oceano Índico, há outros países nessa separação entre Angola e Moçambique. Basta ver que são países com realidades e histórias diferentes, cada um tem uma história colonial, e até de certo modo por esta distância entre 
países lusófonos, Moçambique tem maior contato e relações com países de expressão inglesa, os da Commonwealth. Até mesmo ao conduzir ou dirigir um carro, os Moçambicanos não conduzem pelo mesmo sentido como nós, devido a influências como as inglesas, a condução chamada "de mão inglesa".

Quais são as perspectivas, na opinião de vocês, de presente e futuro dessa aproximação Brasil-Angola, sobretudo na área da educação, que é a área em que vocês atuam lá, para quem vem fazer esse intercâmbio de estudos e pesquisas?

JH: Se calhar agradecer, já que estamos no fim, hoje tivemos um dia pesado, cansativo, e produtivo acima de tudo, porque estivemos a participar das mesas-redondas que tiveram debates cerrados em muitos pontos. São pontos de vista que irão trazer dados novos sobre aquilo que é historiografia africana, angolana. Sabemos que o Brasil é um país, um continente enorme, já tem sua independência já há muitos anos, ao contrário da nossa, por isso já deu passos significativos em ponto de vista de ensino, em ponto de vista de educação, tanto que grande parte dos quadros, ou muita gente de Angola vem para o Brasil para se formar, acaba sendo uma referência internacional no ensino. Quem está aqui pode não sentir isso, mas quem é de outro país, está fora, sente o Brasil como centro de ensino, a transmissão de conhecimento é uma referência que se traduz até na questão de ser hoje a sétima economia do mundo, acredito que não seja possível alcançar esses patamares se não tivesse feito investimento enormes, muito grandes na educação, no ensino formal. Então pensamos que para um maior diálogo entre Brasil e Angola será sempre necessária a realização de colóquios, eventos que possibilitem o encontro de especialistas em matéria de ensino. Isso penso que pode ser bom, novas verdades podem ser discutidas, novas verdades serão debatidas, e com isso vamos indo, melhorando determinados aspectos em que ainda nós achamos que existem lacunas, então penso que esse intercâmbio deve permanecer, de professores brasileiros irem para Angola, para pensarem um pouco sobre aquilo que é da realidade angolana, as práticas docentes, os aspectos culturais, enfim, e encontramos momentos oportunos para os tais debates científicos que vão construir uma historiografia entre Angola e Brasil. Como dizia alguém, nós podemos hoje fazer um determinado debate aqui, um determinado estudo que sempre acontece nas comunidades científicas, e amanhã poderá não acontecer, mas o 
importante é dar sempre qualquer contributo, por mínimo que seja, para aquilo que são as nossas causas. Obrigado.

PM: Quero agradecer a preocupação e, principalmente, à professora Júnia Sales e toda a equipe, que juntos se desdobram com ela na busca e oferta desta visão sobre essa formação que é cultural e nessa questão no diálogo entre Brasil e Angola, principalmente nessa questão do ensino de história. Realmente o Brasil tem sido hoje um horizonte para quem está em Angola e vai ou pretende se firmar e continuar na ciência, tudo por causa das múltiplas formas de como é adotado e abordado o ensino. Olha que foi para mim espantoso, é sempre espantoso, toda vez que ouço falar das preocupações em como são retratados, e o cotidiano, ainda de como se podem fazer leituras e representações existentes do livro didático. Eu começo a dizer, já não tem tempo, já não há nada para estudar, cria-se um pouco e há um certo estranhamento, mas acabamos por entender, depois, o impacto e a necessidade de tais inovações e discussões em processos de ensino...

JH: Eu sou vou cortar sua fala, depois podes continuar. Depois da visita que tivemos em Inhotim, eu fiquei constrangido por uma situação: nas exposições que formos ver só se tratava de negros, aquelas senhoras nuas no estado de deplorável na Bahia, estas nuas num estado deplorável, numa pobreza tremenda, quer dizer, mostrava que o negro só fazia coisas más, ruins, e numa outra mostra e ilustração vi a questão dos indígenas, os índios, então, mas meu Deus, essa sociedade só estuda negros e indígenas?

PM: Então nós achamos que esses diálogos têm sido enriquecedores acima de tudo porque estão permitindo - ainda que aqui não se sinta isso -, mas ao se permitir que nossas ideias atravessem fronteiras, estamos mudando o pensamento de muita gente lá. Tal como esperávamos, e temos percebido isso pelas conversas que temos nos corredores com as pessoas, por aquilo que a gente vai pegando. De tal maneira que é importante que essas "fontes", nós chamamos de fonte, porque é um dado a recorrer, é necessário reconhecer que o Brasil já carrega em si tantos anos de experiência, faz-se uma abordagem de múltiplas formas, a gente aprende cada vez mais, e às vezes a gente pensa assim: "não tenho nada para dar, não tenho nada para ensinar", mas quando a gente trava um diálogo, quando a gente expõe algo às pessoas, acompanham atentos a nossa exposição. Às vezes, a gente não se dá conta dessa nossa contribuição, mas os que nos ouvem se apropriam daquilo, traduzem e contextualizam em seu 
proveito. Nós sentimos isso durante as aulas com a professora Júnia, sentimos isso na professora Samira, e foi assim com todos os professores que dialogam e trabalham conosco, como temas de Angola e África abrem o espaço para interagir. Por isso, achamos que é importante isso, estar a ajudar, estar a mudar a visão do ensino, estamos a enriquecer as nossas aprendizagens, quer de vosso lado quer do nosso lado, e isso é lindo. Nós também propiciamos a criação de um grupo de estudos africanos na UFMG, que a maioria de nós abraçou. E vão forjar várias parcerias em diferentes linhas de nossas atuações.

\section{Aqui ou lá?}

PM: Aqui, com o professor Luiz Alberto Oliveira, e com a professora Nilma Lino Gomes também estamos em um outro programa, um projeto que foi para a CAPES e do qual farão parte alguns professores da FaE e nós, os orientandos de Angola. A ideia é de que vamos desenvolver parceria de mobilidade e intercâmbio de estudantes e professores, porque nós vamos entrando nas historiografias e em algumas abordagens nos sentimos limitados, porque viemos desprevenidos. Nós pensamos que quando chegássemos a Brasil era para ter somente aulas, depois das aulas voltar para Angola, mas aqui a realidade é outra, abrem-se muitas oportunidades e nós sentimos estar também a contribuir com as mudanças de algumas atitudes até de professoras e professores que estão aqui na FaE, aqui na UFMG, por a gente estar a dar opiniões, então isso é importante. E podem contar conosco depois de irmos, o contato não acabou, temos aí os e-mails, há uma programação, quer-se fazer uma abordagem, há um colóquio, um seminário... nos convidem! Basta dizer "gostaríamos de convidar, e se puder arrumar mais alguém para juntos participarem de nossa atividade e construir mais um saber...”. Isso vai ser muito importante.

E antes que se diga que o Paka fala muito [risos], tal como se diz em língua ibinda: "baka ma muali, tuba li mueka", ou seja, "se tiveres muitos assuntos para dizer, fale apenas o mais importante". Ou ainda, "quem muito fala acaba por errar...”. Por último, quero agradecer ao grande amigo Luciano Roza.

JH: Sempre com aquele olhar crítico.

PM: Estamos sempre a fazer comparações, a puxar aspectos positivos... Muito obrigado, estamos à disposição. 


\section{NOTAS}

${ }^{1}$ IMNE: Instituto Médio Normal de Educação "Suka-Hata", hoje Escola de Formação de Professores de Cabinda (EFP).

${ }^{2}$ Escola de formação de Professores da ADPP (Ajuda do Desenvolvimento do Povo para Povo). Uma escola ou ONG dinamarquesa que, desde 1997, vem se dedicando à formação de professores do I Ciclo essencialmente e cujos formandos estão vocacionados a atuarem em zonas rurais em nível primário.

${ }^{3}$ INIDE: Instituto Nacional de Investigação e Desenvolvimento da Educação.

${ }^{4}$ Termo de gíria angolano, advém das zungueiras (mulheres e, até certas vezes, homens) que vendem seus produtos pelas ruas da cidade, às vezes transportando-os na cabeça $\mathrm{e}$ rodeando pela cidade toda à procura de possíveis compradores; zungar - rodear à procura de quem compre seus produtos.

${ }^{5}$ Do termo quitanda - mercado, praça; ou seja, quitandeira é quem vende nos mercados informais. Ambos os termos podem ainda significar vendedor ambulante.

Entrevista recebida em 24 de setembro de 2014. Aprovada em 23 de outubro de 2014. 